Studies in African Linguistics

Volume 36, Number 1, 2007

\title{
NOUN PHRASE AND CLAUSAL CONNECTIVES IN AKAN*
}

\author{
Nana Aba Appiah Amfo \\ Norwegian University of Science and Technology / University of Ghana
}

This paper explores the semantics and pragmatics of noun phrase and clausal connectives in Akan (Niger-Congo, Kwa branch), highlighting dialectal variation. In Fante, noun phrases may be conjoined by nyé which encodes comitativity, or $n \grave{a}$, which is underdetermined between comitative and coordinative meanings. Asante, on the other hand, uses the underdetermined noun phrase connective né. The interlocutor in Asante thus relies on contextual information to determine the intended interpretation. Clausal conjunction in both dialects is

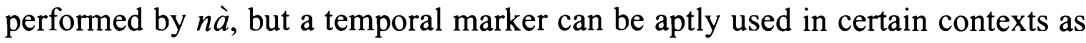
an alternative to the clausal connective. This situation, where the temporal marker functions as a clausal connective, is more general in Fante where the temporal marker is even used in certain contrastive contexts. This phenomenon demonstrates the close conceptual affinity between temporal markers and clausal coordinators.

\section{Introduction.}

This paper examines noun phrase and clausal conjunction in the Niger-Congo (Kwa) language Akan, and attempts to trace the origin of the noun phrase connective $n(y) e ́$. It is observed that its comitative origin is reflected in its contemporary semantics; however, there is significant dialectal variation regarding noun

\footnotetext{
* I wish to thank Thorstein Fretheim and Kweku Osam for their careful reading and comments on earlier drafts of this paper. I am also grateful to an anoynymous referee and David Odden, for their detailed insightful comments. My informants Fauziatu Tijani, Yvonne Agbetsoamedo, Yvonne Otoo and Frank Amfo deserve my appreciation, as well as my collegues Grace Bota, Clement Appah and Kofi Agyekum for helpful discussions and comments. Any remaining shortcomings are my own.
} 
phrase conjunction in two major dialects of Akan, Asante (Twi) and Fante. This observation is in consonance with Mithun's (1988) suggestion that the most common source of noun phrase connectives ${ }^{1}$ is comitative constructions and adverbials meaning 'also'. On the other hand, she attributes the source of clausal connectives to discourse adverbials. It will be shown here that even though Akan has a clausal connective nà, the temporal marker ná / nńà is gradually assuming functions originally reserved for the ordinary clausal connective.

The noun phrase connective ne in Asante may give rise to either a comitative or a coordinative interpretation in its use.

(1) Àkósúa né Kòfi sà -è. ${ }^{2}$
Akosua CONJ Kofi dance
'Akosua and Kofi danced.'/
'Akosua danced with Kofi.'

Example (1) could be interpreted comitatively, that is, Akosua danced with Kofi as a pair: in other words, they cooperated in that specific act of dancing. On the other hand, (1) could be uttered to describe a situation where on a given occasion Akosua danced as well as Kofi: they may have danced with different partners or on their own.

It is worth noting that comitativity semantically entails coordination. However comitativity involves an additional level of cooperation and accompaniment, which is not necessarily encoded in coordination. In most instances, one of the participants takes a lead role with the other(s) complying and cooperating in the action. For instance, a comitative reading of (1) could suggest, within an appropriate context, that the referent of one of the conjunct noun phrases picked the

${ }^{1}$ In this paper, I use the label "connectives" in reference to those lexical items which conjoin noun phrases and clauses, while I reserve the term "conjunction" for the whole structure of conjoined phrases and clauses. Tones have been marked in the examples: ' (for low tone), (for high tone) and '' (for downstepped high).

2 The abbreviations used in this paper are as follows: $\mathrm{CM}=$ conditional marker; COM=comitative connective; $\quad$ COMPL $=$ completive $\quad$ aspect; $\quad \mathrm{CONJ}=$ connective; CONS=consecutive marker; $\mathrm{DCM}=$ dependent clause marker; $\mathrm{DEF}=$ definite article; $\mathrm{FUT}=$ future tense; $\mathrm{IMP}=$ imperative; $\mathrm{MM}=$ modal marker; $\mathrm{MP}=$ motional prefix; $\mathrm{N}=$ =noun; $\mathrm{NEG}=$ Negative morpheme; $\mathrm{NP}=$ noun phrase; $\mathrm{PERF}=$ perfect aspect; $\mathrm{POSS}=$ Possesive marker; $\mathrm{REL}=$ relative clause marker; $\mathrm{VP}=$ verb phrase. 
other out of a crowd for a dance. In other words, one of them was the initiator and controller of the action, while the other complied and cooperated.

As example (1) illustrates, it is not always possible to distinguish a comitative use from a coordinative use of the connective né, using only a given utterance as a basis. Is this form a case of polysemy then? In consonance with Carston's (2002) underdeterminacy thesis, characteristic of relevance theory (Sperber and Wilson 1995), I proffer a univocal lexical semantics. This sense generality view is also in conformity with Grice's Modified Occam's Razor, which states that "senses are not to be multiplied without necessity" (Grice 1989: 47). I suggest that this lexical item is underspecified between these two meanings; contextdependent inference at the pragmatic level combined with the semantics of other expressions used in the utterance help in determining the specific meaning intended for a given utterance. Cross-linguistically, the frequent grammaticalization of comitative markers into coordinative markers is an indication of the close affinity between these two semantic domains. This is evidenced by the fact that in many languages, including Ewe (Lord 1973, Heine and Reh 1984); Ga, Yoruba (Lord 1973); Hausa (Abdoulaye 2004) and Miya (Schuh 1998), noun phrase comitative and coordinative connectives have identical segmental form and similar syntactic properties.

The Fante noun phrase connective nyé, on the contrary, encodes a comitative meaning and is only used in contexts where a comitative interpretation is intended. What example (2) says is that Esi and Kofi cooperated in the act of playing, participating together in a single (or several) game(s).

$\begin{array}{lll}\text { (2) Éśi nyé Kòfi dź-ì ànór. } & \text { án } \\ \text { Esi COM Kofi eat-COMPL game } & \text { 'Esi played with Kofi.' } & \end{array}$

When a speaker of Fante intends a coordinative interpretation for a noun phrase conjunction, she resorts to the connective nà, which also serves as the clausal coordinating connective in both dialects. Example (3) gives no linguistic indication that Kofi and Esi played together, and they may have played different games or even played with different partners or at different places.
$\begin{array}{lllll}\text { (3) Ésí nà } & \text { Kòfí dź1-ì } & \text { àgór. } \\ \text { Esi } & \text { CONJ } & \text { Kofi } & \text { eat-COMPL } & \text { game }\end{array}$
'Esi and Kofi played.' 
These facts notwithstanding, the underspecified nature of the conjunction $n a ̀$ allows it to be used to conjoin noun phrases in Fante even when a comitative interpretation is intended. Indeed, the inferential relations existing between the noun phrase conjuncts could either be one of accompaniment or of equal ranking.

At the clausal level, the high-toned adverbial marker ná may sometimes be

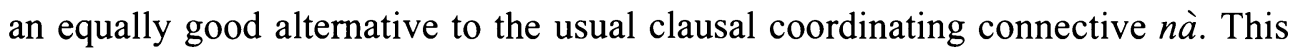
phenomenon is even more extensive in the Fante dialect (see section 5.2). It is shown there that the adverbial marker and the coordinating connective may sometimes have overlapping functions. This is not altogether surprising considering Mithun's (1988) observation that adverbial markers may often be the source of clausal connectives.

One of the claims of this paper is that the Asante noun phrase connective $n e ́$ is underdetermined between a comitative and a coordinative meaning. What it encodes is a "togetherness" relation between the noun phrases it conjoins. As to whether this relation is one of accompaniment (as in a comitative conjunction) or both noun phrases are of equal ranking (as in a coordinative conjunction) is left to pragmatic inference. Fante nyé on the other hand encodes an accompaniment relation between the noun phrase conjuncts. I have argued elsewhere ${ }^{3}$ that the clausal connective nà provides procedural information to the effect that the $n \grave{a}$ utterance achieves relevance as a single unit and that it indicates that some kind of inferential relations exist between the conjuncts. When $n a$ is used as a noun phrase connective in the Fante dialect, what changes is the scope of its operation, from the clause level to the level of the noun phrase.

The rest of this paper is organized as follows: section 2 deals with noun phrase conjunction. The first subsection, 2.1, looks at the comitative and coordinative encoding strategies of noun phrase conjunction. This is followed in subsections 2.2 and 2.3 by descriptions of the nature of noun phrase conjunction in the Fante and Asante dialects respectively. Section 3 examines the origin of the comitative connective. Sections 4 and 5 focus on clausal conjunction, where the former deals with the clausal connective $n \grave{a}$, and the latter examines the communicative role of the temporal marker $n a$, stressing its overlapping role with the clausal connective $n a \grave{a}$. In subsection 5.1 the role of ná in the Twi dialects is established as a temporal marker which provides a temporal constraint on the proposition expressed in the ná-clause. In the final subsection 5.2, it is established that the closest Fante equivalent of the Twi temporal marker has more varied

${ }^{3}$ An extensive discussion of clausal conjunction involving the connective nà is found in Amfo (2007). 
communicative roles which includes acting as an ordinary clausal connective. Section 6 is the conclusion.

\section{Noun Phrase Conjunction. ${ }^{4}$}

This section focuses on noun phrase conjunction in Akan. Section 2.1 considers the coordinative and comitative encoding strategies of noun phrase conjunction, and 2.2 and 2.3 investigate the semantic and pragmatic variations in Fante and Asante, respectively.

2.1 Encoding strategies. Many languages of the world including a number of Sub-Saharan African ones, use disparate forms to coordinate noun phrases and clauses. As shown in (4) and (5), Ewe, a Kwa language, uses kple for noun phrases and eye for clauses. For $\mathrm{Ga}$, another Kwa language, it is $k \varepsilon$ for noun phrase conjunction and $n i$ for clauses, as illustrated in (6) and (7).

(4) Koku kple Aku duye.

Koku CONJ Aku dance.PST

'Koku and Aku danced.'

(5) Koku dure eye Aku fo vu -a -wo.

Koku dance.PST CONJ Aku play.PST drum-DEF-PL

'Koku danced and Aku played the drums.'

(6) Oko ke Akwele jo.

Oko CONJ Akwele dance.PST

'Oko and Akwele danced.'

(7) Oko jo ni Akwele ji joo $l \varepsilon$.

Oko dance.PST CONJ Akwele beat.PST drums DEF

'Oko danced and Akwele beat the drums.'

${ }^{4}$ The Akan data used in this paper is from two dialects, Asante and Fante. They are from written texts, invented examples and tape recordings from radio discussions. The examples are marked as follows: (FT) for Fante text, (AT) for Asante text and (RTR) for radio tape recordings. The various dialects are indicated by (As) for Asante and (Fa) for Fante. 
In Standard Hausa, a Chadic language, noun phrases are conjoined by da (Newman 2000: 138-140). There is no single overt clausal connective. Conjoined clauses are simply juxtaposed, and may have other markers such as kuma ('also, in addition') linking them. ${ }^{5}$

Akan also uses separate markers for noun phrase and clausal conjunction. Welmers' (1973: 372-3) assertion that both noun phrases and clauses and even verbs are conjoined by $n \grave{a}$ or nńà is only partly true. First, he was (over)generalizing with data from one major dialect, Fante. Second, even though nńà may qualify to a certain extent as a clausal connective (see section 5.2), it does not conjoin noun phrases. Neither form conjoins verbs. Contrary to Welmers' assertion, verbal conjunction in Akan patterns very much like the other languages in his study.

In Asante, né is used for noun phrases and nà for clauses, as can be seen from examples (8) and (9). Fante uses nyé or nà for noun phrase conjunction, as in (10), and uses nà for clausal conjunction, as shown in (11). ${ }^{6}$

Màmé Yàá né Ámá kó ásòpíti.

Maame Yaa CONJ Ama go.PERF hospital

'Maame Yaa and Ama have gone to the hospital'/

'Maame Yaa has gone with Ama to the hospital.' (As)

(9) Mààmé Yàá kó ásòpitì nà Á!má kó sùkúù.

Maame Yaa go.PERF hospital CONJ Ama go.PERF school

'Maame Yaa has gone to the hospital and Ama has gone to school.'

${ }^{5}$ However Ghanaian Hausa uses $d a$ for noun phrase conjunction and shei for clausal conjunction as in (i) and (ii):

(i) Sule da Fati sun yi rawa

Sule CONJ Fati they.PST do dance

'Sule and Fati danced.'

(ii) Sule ya yi rawa shei Fati ta bugakalangun

Sule he.PST do dance and Fati she.PST drum(s).DEF

'Sule danced and Fati played the drums.'

${ }^{6}$ For ease of presentation, I will restrict myself to conjunctions involving two conjuncts. The semantic and pragmatic implications remain the same irrespective of the number of conjuncts. 


\section{(10) Àfèdzì nyé /nà Ésí kò kùróm. \\ Afedzi COM /CONJ Esi go.PERF town \\ 'Afedzi has gone to town with Esi.'/ \\ 'Afedzi and Esi have gone to town.' (Fa)}

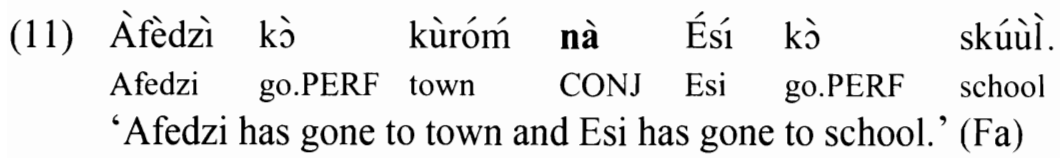

The forms which conjoin noun phrases are mostly of comitative origins, and it has been argued that some of the forms are still essentially (semantically) comitative rather than coordinating connectives, which may be undergoing processes of grammaticalization. In his study of noun phrase conjunction, Stassen $(2000,2003)$ distinguishes between languages in which noun phrase conjunction is encoded by either a coordinative or a comitative strategy. ${ }^{7}$ He refers to languages which use the comitative strategy as the only means of encoding a situation in which a single event is attributed concurrently to two different participants, as WITH-languages, citing Akan as an example. Languages which clearly distinguish between comitative and coordinative encoding, like English, he calls AND-languages. Stassen concedes that a few languages show that the comitative/coordinative dichotomy cannot always be pursued faithfully. My suggestion is that Akan, which he categorizes as a WITH-language, is one of these languages. Conjunct noun phrases in an Akan phrasal conjunction do not exhibit any morphosyntactic properties which indicate an unequal structural rank between them. Thus an intended comitative strategy can only be contextually determined. Dialects vary as regards the connectives used. Akan generally does not have subject-verb agreement. Verbs inflect for tense, aspect and polarity, but not for number. ${ }^{8}$ As a result, one cannot use subject-verb agreement as a criterion for determining whether or not the conjoined noun phrases form a constituent. In the following subsections, I will give a clearer picture of the Akan situation.

${ }^{7}$ Stassen (2003: 780) suggests that the coordinative strategies have the following characteristics: NPs have same structural rank and they form a constituent. There is plural or dual agreement on verbs, and a unique coordinative particle. With regard to the comitaitve strategy, the NPs differ in structural rank and do not form a constituent. There is singular agreement on verbs, and a unique comitative particle.

${ }^{8}$ However there are limited cases in which a reduplicated verb needs to have a plural subject or object or both. Such a phenomenon is usually not a mere syntactic requirement but it is also of some semantic and or pragmatic significance. 
2.2 The Fante situation. A Fante speaker has the option of conjoining two noun phrases with either nyé or nà.

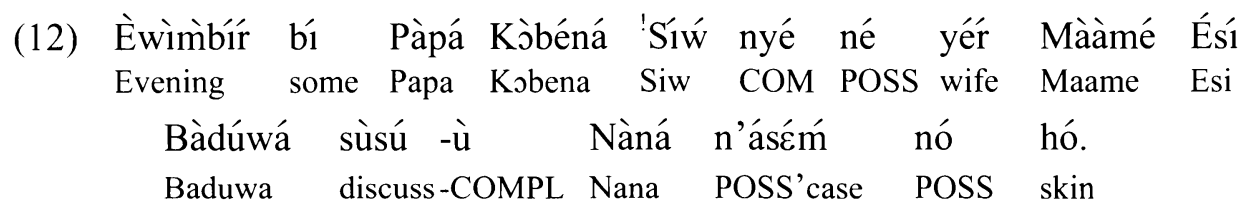

'One evening Papa Kobena Siw discussed Nana's suggestion with his wife Maame Esi Baduwa.' (FT) ${ }^{9}$

The use of nyé may be said to signify at least two things. First, the action described by the verb susuu (discussed) is considered to have been jointly performed by the referents of the two conjoined proper nouns - Papa Kobena Siw and Maame Esi Baduwa. In other words, there is a cooperative relation between the two conjoined subjects and the event described. Second, with the aid of contextual information it can be said that one of the participants, in this case the wife, is 'backgrounded' in the event described here. Papa Siw is presented as the initiator and controller of the discussion and indeed the protagonist of that portion of the narration.

The choice between nyé or nà depends on whether or not a speaker of Fante intends to encode a comitative interpretation. In (13), it is quite obvious that Papa Siw, who is the father of Kodwo and Araba, is seen as the initiator and performer of the action of going to school, with Kodwo and Araba being obliged to come along.
(13) Pàpá Síw
nyé Kòdwó nà
Árábá kó -j̀
skúùì hó.
Papa Siw
COM Kwadwo
CON
Arab
go -COMPL school there
'Papa Siw went with Kwadwo and Araba to the school.' (FT)

Kodwo and Araba form an inner coordinative conjunction which is then conjoined comitatively with Papa Siw, and they all together form a conjoined subject for the verb kos (went) as shown in (14). The first proper noun is on a different

${ }^{9}$ For ease of presentation, (12) has been simplified; the original sentence is the following: Ewimbir bi Papa Kobena Siw frec ne yer Maame Esi Baduwa nye no susuu Nana n'asem no ho ('One evening Papa Kobena Siw called his wife Maame Esi Baduwa and discussed Nana's suggestion with her'). 
level than the other two; (15) and (16) represent ungrammatical alternatives to the outer NP structure of (14). ${ }^{10}$

$\left[\mathrm{N} \text { nye }[\mathrm{N} \text { na } \mathrm{N}]_{\mathrm{NP}}\right]_{\mathrm{NP}} \mathrm{VP}$

(15) $*\left[[\mathrm{~N} \text { nye } \mathrm{N}]_{\mathrm{NP}} \text { na } \mathrm{N}\right]_{\mathrm{NP}} \mathrm{VP}$

(16) $*[\mathrm{~N} \text { nye } \mathrm{N} \text { na } \mathrm{N}]_{\mathrm{NP}} \mathrm{VP}$

If a tripartite noun phrase conjunction involves a comitative as well as a coordinative interpretation, then the conjunct noun phrase which is involved in the comitative interpretation must be the first or last member of the conjunction

The use of nyé indicates some form of accompaniment, which can only be deduced contextually when $n a ̀$ is used. For instance, in (17), what is communicated linguistically is that Araba has gone to church, as has Akyere.

(17) Árábá nà Àkyèré kò
Araba CONJ Akyere
'Araba and Akyer.

The fact that the interlocutor may interpret the speaker to mean that the two have gone to church in the company of each other may be the result of extra-linguistic information. The use of nà gives rise to the possibility that the two ladies mentioned might have left home at different times, going to different churches. Even if they did go together, the relevance of a token of (17) would not necessarily be affected by the interlocutor's choice of the stronger or the weaker explicature ${ }^{11}$ interpretation.

An interpretation that the ladies left at separate times or went to separate churches is ruled out when nye is used in place of nà, as in (18).

${ }^{10}$ Example (14) is intended as a syntactic representation of (13) and not a general representation of any possible tripartite conjunction involving nyé and nà. What determines which two conjunct NPs in a tripartite conjunction, involving both nyé and nà, form a closer constituent does not depend solely on the choice of a particular connective or syntactic position but also on pragmatic factors.

${ }^{11}$ An explicature, according to Carston (2002: 377). is "an ostensively communicated assumption which is inferentially developed from one of the incomplete conceptual representations (logical forms) encoded by the utterance". It is contrasted with an implicature which is derived purely inferentially. 


\section{(18) Árábá nyé Àkyèré kò àsór. \\ Araba COM Akyere go.PERF church \\ 'Araba has gone to church with Akyere.' (Fa)}

The very existence of the opposition between nà and nyé in a pair like (17-18) presumably makes the separate events interpretation relatively more accessible than the stronger, joint action interpretation when the connective is nà as in (17). One might expect the unambiguous nyé to be used if the stronger interpretation is intended.

In summary, when nà is used to conjoin noun phrases, the choice between a coordinative and a comitative interpretation is determined by other contextual information such as previous knowledge or even perception. On the other hand, nyé linguistically encodes a comitative meaning; the two participants will have to be involved simultaneously in the event described, with one of the participants being backgrounded. Thus Fante falls in line with Stassen's assertion that languages with comitative as well as coordinative noun phrase encoding strategies typically use different markers for these purposes. However, even though nyé does not seem to be an option when a coordinative interpretation is intended, nà is compatible with a comitative interpretation.

2.3 The Asante situation. Asante has a single marker né which conjoins noun phrases. Consequently, a comitative vs. a coordinative interpretation can only be determined from the context. The Asante version of (13) will be rendered as (19) below. $^{12}$

\section{(19) Pàpá Síw né Kòdwó né Árábá kò -j̀ sùkúù hó. \\ Papa Siw CONJ Kodwo CONJ Araba go -COMPL school there \\ 'Papa Siw went with Kodwo and Araba to the school.'}

In (19), the knowledge that Papa Siw is the initiator of the event described here, with Kodwo and Araba simply complying and coming along, can be deduced as a result of knowledge acquired from the context. The fact that Papa Siw is the father here, the older and more authoritative person, combined with knowledge of the fact that he had earlier decided with his wife that they are sending the children

\footnotetext{
${ }^{12}$ The first né in (19) could be omitted when a coordinative interpretation is intended. This is not possible when a comitative interpretation is intended.
} 
to school, will be the contextual input for the interlocutor in opting for a comitative interpretation for the first instance of né in (19). ${ }^{13}$ Also, the fact that Papa Siw is the first member of the tripartite noun phrase conjunction is a relevant structural feature which aids in accessing a comitative interpretation. ${ }^{14}$ Similar background information is what motivates the interlocutor in choosing a coordinative interpretation for the marker né conjoining Kwadwo and Araba.

The two noun phrases in (20) are both inanimate (abstract) nouns. Hence a coordinative rather than a comitative interpretation would be the one intended for that conjunction, since one of them cannot be seen as an accompaniment to the other. For a comitative reading to be possible, both noun phrases will have to be animate.

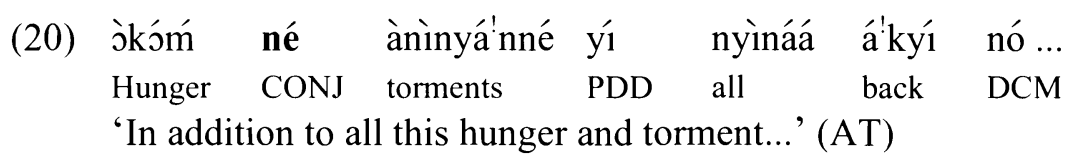

\section{Origin of the Comitative Marker.}

It has been suggested that comitative connectives in a number of languages may have originated from verbs. Abdoulaye (2004) assumes that the Hausa comitative marker $d a$ can be traced to the existential verb $d a$. Lord (1973) supposes verbal origins for the Yoruba, Ga and Ewe noun phrase connectives. ${ }^{15}$ Stassen $(2000$,

${ }^{13}$ Another comitative strategy in Akan is to use the defective verb $d(z) e$ (take), which also has an instrumental or manner function. (19) could be correctly rendered as Papa Siw de Kodwo ne Araba kэ sukuи ho. In cases where the noun phrases involved are animate and inanimate,

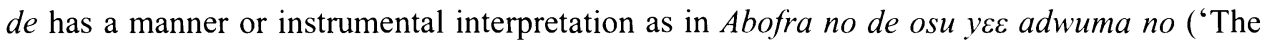
child did the job in tears') and Maame no de sekan twaa nam no ('The woman cut the meat with a knife').

${ }^{14}$ On the comitative interpretation, (19) is still vague as to whether Papa Siw went with Kwadwo at one time and with Araba at another time, or whether he went with Kwadwo and Araba at the same time. As always, contextual information will be crucial in resolving this vagueness.

${ }^{15}$ Kple, according to Lord (1973), is characterized as a verbid by Ansre (1966), and it is the only verbid which lacks a homophonous regular verb counterpart. Given this situation and its syntactic behaviour, Lord speculates that kple could have existed as a regular verb during an earlier period with similar semantics as the Yoruba verb kpelu ('be together with'). This speculation is confirmed by Heine and Reh's (1984) analysis which suggests that kple might 
2003) suggests that noun phrase connectives in Choctaw, Korean and Classical Mongolian have their sources in the verbs meaning 'to be' or 'to exist'. It is quite evident that the Akan comitative marker $n(y) e$ has evolved out of a verb. Indeed this marker still exhibits some traces of verbal morphology, and more so in Fante than in Asante.

The only thing indicative of the verbal status of Asante né is the fact that it can take some pronominal prefixes as shown in (21).

(21) j̀ -né máàmé rè -nòá àdùàné.
s/he -CONJ mother PROG -cook food
'S/he is cooking with mother.' (As)

As part of their morphology, verbs in Akan take on tense, aspect, polarity and subject pronominal affixes. ${ }^{16}$ The use of the pronominal prefix 0 - in (21) could be taken as a trace of the original verbal status of the form né. This is against the backdrop that connectives do not take on pronominal affixes. On the other hand the orthographic convention of not prefixing other pronouns like the first person singular pronoun to né as in (23) below, plus the general absence of tense-aspect markers on this form, is an indication of the categorial shift of this word. Moreover, the rigidity of the syntactic position of né may be a relic of its verbal status. As a comitative marker $n(y) e$ (together with its complement) cannot take other positions such as the adverbial position in the clause.

In Fante, nyé displays more verbal morphology than its Asante counterpart. In addition to taking on the pronominal subject prefixes, nye can also have the negative (nasal) marker affixed in negative sentences. Indeed, in the negative form, nyé may take on other tense-aspect markers such as the completive aspect marker. Thus in a typical serial verb construction style (22), the main verb $k J$ ('go') is negated and has the completive aspect marker just as nyé does, while the

have developed from the verbs $k p e$ ('meet') and $d e$ ('get to'). The verbal status of $k \varepsilon$ is argued for by Trutenau (1973) and confirmed by Dakubu's (1970) auxiliary verb label.

${ }^{16}$ The subject pronouns in Akan are the following me ('I'), wo ('you singular'), sno ('s/he'), $\varepsilon n o$ ('it'), yen ('we'), mo ('you plural'), won ('they'). These full forms are used in isolation or when they are followed by focus markers or connectives, as in the following Fante sentences: ónó ńsó báà há ('s/he also came here'); ónó nà Kơfi káj kùróm ('s/he and Kofi went to town'). When the pronouns are immediately followed by verbs, then the prefixes are used. The single syllable pronouns remain the same but the second syllable of the disyllabic ones are dropped so that ono becomes $\jmath_{-}^{-}, \varepsilon n o$ becomes $\varepsilon^{-}, y \varepsilon n$ becomes $y \varepsilon^{-}$and won becomes $w o-$. 
Asante version in (23) negates only the verb $k s$ ('go'), the double negation and completive form of (24) corresponding to Fante (22) being ungrammatical.
(22)
$\begin{array}{llll}\text { Mè } & \text {-à } & \text {-ǹ } & \text {-nyé } \\ \text { I } & -C O M P L & -N E G & -C O M \\ \text { 'I didn't go with her.' (Fa) }\end{array}$

(23) Mè né 'nó à -ǹ $-\mathrm{kó}$.

CONJ her COMPL -NEG -go

'I didn't go with her.' (As)

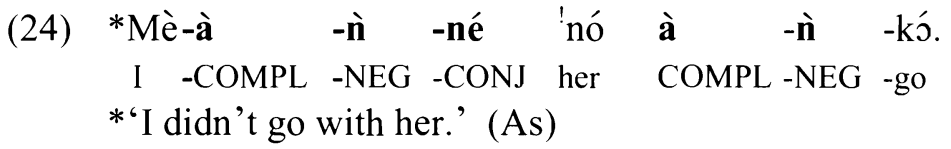

Thus one can conclude that $n(y) e ́$ has verbal origins and is evolving as a connective. The grammaticalization process can be said to be quite advanced for Asante né; however, the same cannot be said for Fante nyé. In the language of most Fante speakers nyé does inflect in the negative form, though it is not uncommon to find some younger speakers omitting some tense-aspect inflection on nyé.

Given that the Akan comitative marker originated from a verb, the next puzzle concerns the semantic nature of that verb. Mithun (1988) suggests that a regular source of noun phrase connectives is adverbials and comitative verbs. Stassen (2003) submits other diachronic possibilities. These include numerals or quantifiers such as 'two', 'both' and 'all', as well as non-finite forms of verbs meaning 'to be' or 'to exist'. If Stassen's assertion is correct, then it is not surprising to find that there is an identificational copula in the language identical to the comitative marker. This identificational copula may well be the source of the comitative marker in Akan.

As a verb, $n(y) e ́$ may be used to introduce indirect speech in narrations. In the Fante example (25), the writer reports about what happened at a meeting with the Chief of Mensakurom. He narrates what the chief said by introducing it with nyé plus the complementizer $d \varepsilon$, to indicate that he is not responsible for the content of the indirect speech to follow. In (26), both the speaker (narrator) and interlocutor (readers) are aware that since a question has been asked an answer was given, justifying the use of né. 

(25) Dzàà Nàná ká -à biò nyé dé òbiárá me -fá What Nana say-COMPL again be COMP everyone IMP -take né bà me -brá má wó -n -kyérèẁ né dzín POSS child IMP -come give they -IMP-write POSS name wò skúù nó mù. be.at school DEF inside

'What Nana said again was that everyone should send the child to be registered at school'. (FT)

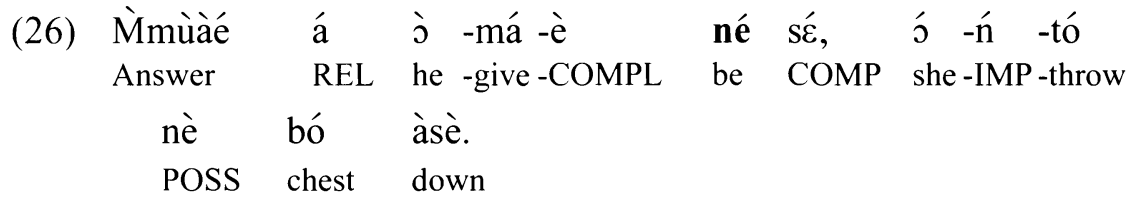

'His answer was that she should be patient.' (AT)

What né as an identificational copula and as a verb introducing indirect speech have in common is that the use of either presumes the existence of the entity it introduces. For instance, the speaker of (27) uses né, rather than $y \varepsilon$, because there is the presupposition that Otieku has a mother, who was probably expected at the scene of the utterance.

(27) Yèf'ré mè Yàa Sèc̀wáá. Mé né Òtı'ékú mààmé.
We-call me Yaa Serwaa. I be Otieku mother
'I am Yaa Serwaa. I am Otieku's mother.' (As)

One piece of syntactic evidence linking the identificational copula $n(y) e$ to the connective $n(y) e ́$ is that, as observed by Ellis and Boadi (1969), $n(y) e ́$ occurs in the syntactic frame NP_NP, whereas $y \grave{\varepsilon}$, another identificational copula, ${ }^{17}$ occurs in either one of these three frames: NP_NP, NP_Adjective or NP_Numeral. The syntactic frame for the copula $n(y) \bar{e}$ is the same as that for the noun phrase connective $n(y) e . Y \grave{\varepsilon}$ can be followed by an adjective or a numeral but both copula $n(y) e ́$ and connective $n(y) e ́$ are only followed by noun phrases.

\footnotetext{
${ }^{17}$ As an existential copula, $n(y) e$ contrasts with $y \grave{\varepsilon}$. $Y \grave{\varepsilon}$ is used in contexts where the speaker does not have any presuppositions; the information given is simply asserted. On the other hand, $n(v) e$ can only be used when both the speaker and the interlocutor presuppose the existence of the entity being introduced, even though the interlocutor may not be familiar with it.
} 
Given that noun phrase connectives in some languages have originated from non-finite forms of identificational or existential copulas, and given what obtains in Akan as described above, one can thus extrapolate to the conclusion that the noun phrase connective $n(y) e ́$ in Akan has its source in the same identificational copula. Akan can thus be added to Stassen's list of languages which may have derived its noun phrase connective from the verb 'to be'.

\section{Clausal Conjunction.}

In Akan, clauses are conjoined with the low-toned $n a ̀$ as illustrated in (28) below.

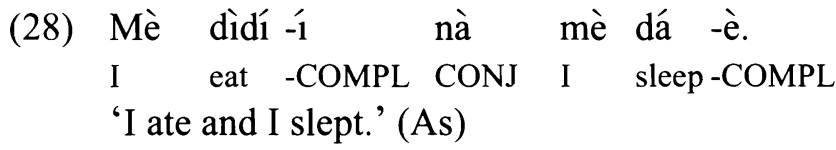

As suggested in Amfo (2007), a nà-conjoined utterance achieves optimal relevance as a single unit. Thus $n a$ is a signal to the interlocutor to look for certain inferential relations between the various conjuncts. A particular inferential relation existing between conjuncts of a given $n \grave{a}$-utterance will have to be contextually determined by combining the encoded meaning of $n \grave{a}$ with other linguistic features of the conjuncts as well as extra-linguistic information derived from the context. These inferential relations as outlined in the above-mentioned publication are temporal, causal, contrastive, parallel and explanatory. This paper will only focus on the temporal relations that exist between $n a$-conjuncts. In (28), the activity described in the second conjunct will be interpreted as having followed the activity described in the first. Given the nature of the activities, a simultaneity reading is ruled out. One kind of $n \grave{a}$-utterance which typically favors a temporal as well as a causal interpretation is one in which the first conjunct contains the dependent clause marker $n o{ }^{18}$ In (29 =Amfo 2007 (9)) Ama's quitting school follows her father's death, and the latter is inferred to be the cause of the former.

\footnotetext{
${ }^{18}$ Since causality often implies temporality such a state of affairs is not surprising.
} 


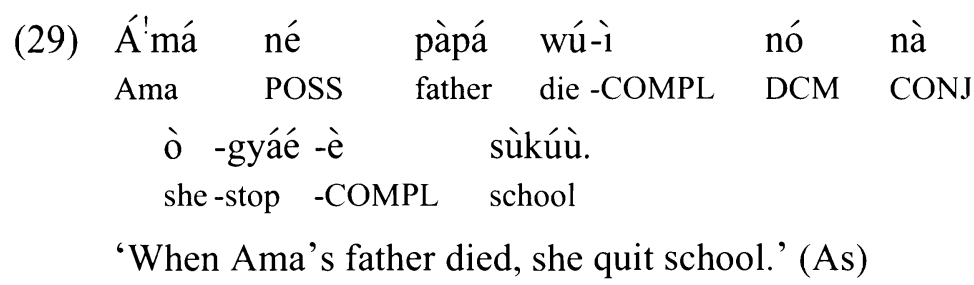

The next section focuses on a segmentally identical but high-toned temporal marker ná, which can often be translated as 'then' (at that time). It will be argued that in the Fante dialect, the equivalent of this marker, nńà, is gradually taking on most of the functions which can be associated with the ordinary clausal connective nà. The situation in Fante is in accordance with Mithun's (1988) prediction that markers which convey meanings such as 'also', 'then', 'and so', 'and now' frequently develop into markers of mundane clausal conjunction.

\section{Temporal Marker ná.}

The temporal marker ná contrasts with the low-toned clausal connective. As mentioned in the previous section, one of the pragmatic relations between conjuncts that the use of the clausal connective nà gives rise to is a temporal one. ${ }^{19}$ Whereas temporality is inferred by the use of $n a ̀$, it is explicitly encoded by ná. Given that the language possesses an almost identical form which encodes temporality, it is not surprising that native speakers may use either of these forms in contexts where some form of temporality is intended to be communicated. That is, native speakers have the choice of encoding the intended temporality or leaving it to pragmatic interpretation. One consequence of this is that either a hightoned or a low-toned na could be used felicitously in certain (temporal) contexts. This trend of a temporal adverb assuming the role of a coordinating connective may be cognitively inspired. Mithun recognizes the significance of the flexibility of the boundary between what she calls discourse adverbials and coordinating connectives. Also, evidence from the Oslo Multilingual Corpus (OMC) pointed out to me by Thorstein Fretheim (p.c.) indicates, for instance, that the French temporal adverb puis (then) can be used as a coordinating connective conjoining two predicates and even two noun phrases.

In this section, I take a look at the high-toned temporal marker ná, in light of its sometimes overlapping pragmatic functions with the clausal connective nà.

${ }^{19}$ Temporality is used broadly to include sequentiality as well as simultaneity. 
This form is mostly used in the Twi (Asante and Akuapem) dialects. In the Fante dialect, its corresponding form is nńa ${ }^{20}$ Even though it can be rightly said that the equivalent of ná in Fante is nnáa, their functions in the two dialects are not identical. Fante nńa appears to have taken on some of the functions traditionally reserved for the low-toned clausal connective. This will be discussed in section 5.2, but first, I look at the communicative role of Twi ná.

5.1 Twi ná. The high-toned ná is a temporal discourse marker with the meaning of 'at that time'. As a temporal marker, the procedural information it provides is for the interlocutor to find a time period expressed in the immediately preceding discourse within which the event described in the ná-clause took (or will take) place. The time period that ná refers to could come in the form of a pre-posed temporal or conditional clause as in (30) and (31) respectively. It could also be expressed as a temporal adverbial preceding the ná-clause, as illustrated in (32). Finally, the time period which ná makes reference to may be located in the immediately preceding discourse, as in (33).

$\begin{array}{lllllll}\text { (30) Kwámè } & \text { dú } & \text {-ù } & \text { Ǹkràǹ } & \text { nó, } & \text { ná } & \text { àbòfrá } \\ \text { Kwame } & \text { arrive } & \text {-COMPL } & \text { Accra } & \text { DCM, } & \text { then } & \text { child } \\ \text { nò } & \text { à } & - \text {-dá. } & & & & \end{array}$

DEF PERF -sleep

'When Kwame got to Accra, (at that time) the child was asleep.' (As)

$\begin{array}{llllllllll}\text { (31) Sc̀ } & \text { wó } & \text { hú } & \text { Àgyèmàn } & \text { à, } & \text { ná } & \text { wó } & \text {-á } & \text {-fré } & \text { mé. } \\ \mathrm{CM} & \text { you } & \text { see } & \text { Agyeman } & \mathrm{CM} \text {, } & \text { then } & \text { you } & \text {-CONS } & \text {-call } & \text { me }\end{array}$ 'Call me if you see Agyeman.'/ 'If you see Agyeman, then call me' (As)

(32) Tètè nó, ná àǹà yè -nànté firì Àbààsá kó Máñò. Ancient.times DEF, then MM we -walk leave Abaasa go Mando 'In ancient times, we used to walk from Abaasa to Mando.' (As)

${ }^{20}$ High-toned $n a ́$ is used in certain Fante constructions such as imperatives, as in the following example: hwehwe no ná bisa no (look for him and (then) ask him). Ná in such contexts typically communicates a temporal ordering of events - do this and then do that. I owe this observation to Kweku Osam. 


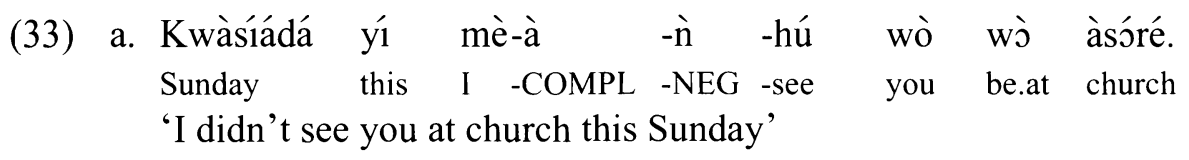

b. Ná mè yáré.
Then I be.ill
'I was ill then.' (As)

When ná is used, the interlocutor has to look for a reference time period activated during the discourse, within which the action described in the clause introduced by ná took place or is expected to take place. In (30), what is communicated by the use of ná is that Kwame arrived at Accra and at the time he arrived, the child was asleep. The event described in the second clause is situated in the temporal period provided by the first clause which ná points out to the interlocutor. When the clausal conjunction nà is used in an almost identical sentence (34), what is most likely to be communicated, in the absence of any contextual indication to the contrary, is a temporal succession of events; Kwame arrived in Accra first, and subsequently the child fell asleep.

(34) Kwámè dú -ù Nkràn nó, nà àbòfrá nó dá -è.

Kwame arrive -COMPL Accra DCM, CONJ child DEF sleep-COMPL

'Kwame arrived in Accra, and then the child fell asleep.'

(The child fell asleep after Kwame arrived in Accra.) (As)

Ná cannot be felicitously used in an utterance like (35), which is a Twi adaptation of an utterance from the Fante text "Woana nye Araba nyinsenii" ("Who impregnated Araba'). The intervening clause annkye ('it did not take long') disallows an interpretation where the event described in the second conjunct took place within the time period described by the first conjunct. The meaning of annkye ("it did not take long') prevents the interlocutor from situating the event described in the following clause within the temporal period described in the preceding clause; the event in the second clause can only be subsequent to the one in the first. As a result, a speaker of Twi cannot opt for a high-toned ná in such a context. ${ }^{21}$ Also the events described in (35) are such that the events in the second clause cannot occur during the same time period as the event described in the first clause.

${ }^{21}$ However the situation in Fante is somewhat different. See section 5.2. 


\section{(35) Àkòkòrá Kòfú Mèn'sá bá -à hó nó à -ǹ Old.man Kofi Mensah come -COMPL there DCM COMPL-NEG -kyé nà nímpá bínóm bé -ká -à nè hó -take.long CONJ people some.PL MP -add -COMPL POSS self \\ 'When Oldman Kofi Mensah settled there, a short time passed and then some people joined him' (As)}

The time period referred to by the marker ná simply provides a temporal reference point for the event described in the clause preceded by ná. Pragmatic relations such as temporal (i. e. sequential) and causal relations which can be inferred from $n a ̀$-conjunctions are blocked from $n a$-constructions as illustrated by the following set of examples (29), repeated here, and (36-37). ${ }^{22}$

(29) Á!má né pàpá wú -ì nó, nà
Ama POSS father die -COMPL DCM, CONJ
ò -gyáè -è
she-stop -COMPL sùkúu.
'When Ama's father died, she quit school.'
(i.e. Ama quit school as a result of her father's death) (As)

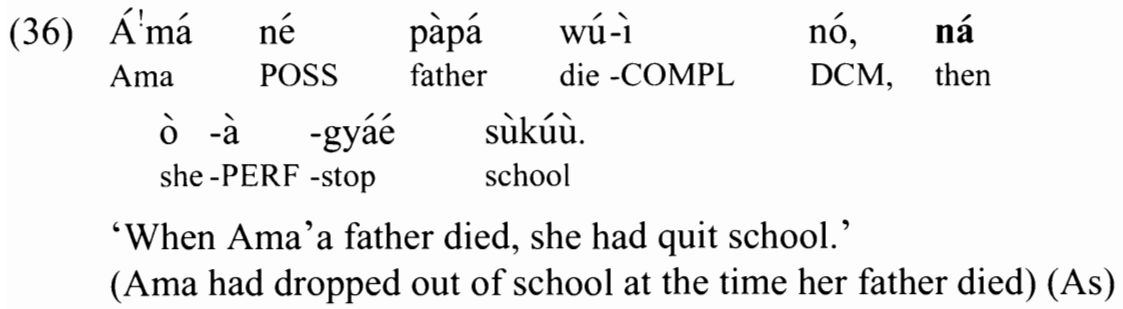

${ }^{22}$ Certain tense-aspects dynamics involved in this set of examples are much too complex to be handled effectively within the scope of this paper. However note that in the context of temporal clauses such as the initial clauses in (29), (36) and (37), no is not optional and this marker is used when the event described is either a past event or a future event which is expected with certainty. It cannot refer to an event which is in progress or one which is continuing in the present time. Also the event described by the ná-clause cannot be completive. 


(37) Ámá né $\begin{aligned} & \text { pàpá wú -ì } \\ & \text { Ama POSS father die -COMPL DCM, then }\end{aligned}$
ò -rè -bè -gyàé sùkúu.
she -PROG

If there is no extra-linguistic information to the contrary, example (29) will be interpreted as indicating that Ama's father died, and she dropped out of school as a result. In (36) and (37), the time/period of Ama's father's death provides a temporal setting for the information provided in the second clauses: she had dropped out of school in (36), and was about to drop out of school in (37).

It may be concluded that the use of nà encodes the information that the conjunction is relevant as a single unit. It follows, then, that diverse pragmatic relations, including temporal ones, can be inferred between the conjuncts. $N a$, on the other hand, is a temporal marker. It indicates a temporal frame within which the ná-utterance takes place.

5.2 The situation in Fante. As mentioned at the beginning of this section, the closest Fante equivalent of the temporal marker ná, is nńà. However, nńà, compared to its Twi counterpart, is used in a wider range of situations. The first function that can be attributed to nńà is parallel to its Asante counterpart, ná. Nńà will be the most appropriate form in the place of Asante ná in examples (30) to (33), (36), and (37).

In addition to its similarity in function to Asante ná, nnáa has other functions which overlap that of the low-toned clausal connective nà. Some pragmatic relations which can be inferred between conjuncts by the use of the clausal connective nà are communicated with the use of nńa. These relations could be sequential, causal/consequential, simultaneous, or contrastive.
Mò -hór -r
àdzé
ńnà
mó-nóá -à
èdzibàn.
I -wash -COMPL thing
then
I -cook -COMPL
food
'I did some laundry and cooked.' (Fa)

The use of nńa in (38) strongly communicates a sequential relation between the two clauses. That is, the activity described in the first clause occurred before the 
one in the second clause, within a certain time period. As an answer to a question 'what did you do at home today?', the interlocutor will understand that the speaker of (38) first did some laundry and then cooked some food. The alternative connective nà can be used in such a context. Then the fact that the laundry was done before the cooking is attributed to inference. Though this sequential order may be the unmarked interpretation, it can be ruled out with a follow-up utterance. On the other hand, the use of nńà as in (38) forces a sequential interpretation of the order of events as presented. An attempt to immediately follow (38) with an utterance translated as 'but I cooked before I did the laundry' is odd. One can thus conclude that temporality is encoded by nńà, while it is inferred with the use of nà.

Another relation between conjuncts that arises as a result of the use of nnà is causality. Example (39) could be an appropriate response to the question 'how come Ebo has a cut on his mouth?'. The communicated message in (39) is that Kojo beat up Ebo, and Ebo had a cut as a result of that beating. In other words, Ebo had a cut on his mouth during that thrashing. Again this utterance is equally apt with the connective nà. Given the relation between violence and wounds, such an utterance is enriched in online interpretation to communicate the information that the cut was as a result of the beating. As in (38), nńà in (39) encodes temporality. The conjunct which precedes nńà occurred first. However this temporality is enriched in context so that the interlocutor infers a cause-consequence relation between the conjuncts.

$\begin{array}{llllll}\text { (39) Kòjó bór -r } & \text { Èbó nó, ńnà n’ á!nó pé -è. } \\ \text { Kojo } & \text { beat -COMPL } & \text { Ebo DCM, then POSS' mouth cut -COMPL }\end{array}$ 'Kojo beat Ebo and he had a cut.'

(Ebo had a cut on his mouth as a result of Kojo's beatings) (Fa)

Simultaneity is another kind of temporal relation which is communicated by the use of nńà. Again, this kind of relation can be inferred from conjuncts by the use of nà. The actions described in the various clauses in such nnáconstructions are deemed to be taking place within approximately the same time periods.
(40) Árábá rò -nòá èdzibàn ńnà Éfúa rè -prá.
Araba PROG -cook food then Efua PROG -sweep
'Araba is cooking while Efua is sweeping.' (Fa) 
The situation so far in Fante is as follows. Two types of nńa have been identified. First, there is a temporal marker equivalent to Asante ná ('then'). Second, there is a general temporal connective with a potential to be enriched in context to imply specific temporal relations between the conjuncts, such as sequentiality, cause-consequence relation or simultaneity. Such an account of nńà as a marker of asymmetric conjunction appears neat but for examples like (41) to (42), which further complicate issues. These examples communicate some form of contrast.

(41) Ádjóá yè tùntùm ńnà Á!má yé kòkòó.

Adjoa be black CONJ Ama be red

'Adjoa is dark-skinned, while Ama is light-skinned.' (Fa)

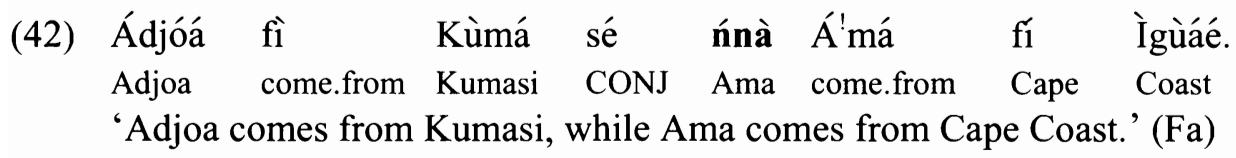

In these utterances where there is some form of contrast between the conjuncts, the connective could well be nà. However, it appears that in utterances where $n \grave{a}$ may be aptly glossed only as 'but', (but not 'while'), nńà does not work as a suitable alternative as in (43).

\begin{tabular}{|c|c|c|c|c|c|c|}
\hline (43) & ?Mè-pغ̀ & kòkòó & ńnà & mé-ḿ & ! & bàǹkyé. \\
\hline & -like & ripe.plantain & CONJ & קГ & & соссой \\
\hline
\end{tabular}

On the other hand, an utterance like (43) is acceptable when the verbs in the two clauses are of the same polarity. Example (44), which is identical to (43) except for the fact that both verbs in the two clauses are negated, is an acceptable utterance in Fante.

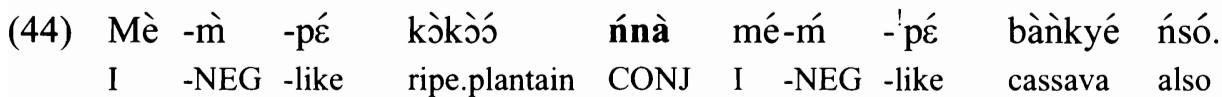
'I don't like ripe plantain and I don't like cassava either.' (Fa)

I conclude this section by suggesting that nńà started out as a temporal marker and it still functions as such. In addition, this temporal marker is being grammaticalized into a connective, while retaining its original function. Its origin 
as a temporal marker is reflected in the temporal relations that often pertain between conjuncts when it is used as a connective. This is in consonance with Hopper's (1991: 22) principle of persistence, which states that "when a form undergoes grammaticization from a lexical to a grammatical function, so long as it is viable some traces of its original lexical meanings tend to adhere to it ...'

As a connective, nńà is used in limited non-temporal contexts, as in (41) and (42). This is an indication that the grammaticalization process from a strictly temporal marker towards a mundane clausal connective, with the potential to be enriched contextually in various directions, is still underway. The use of both nńa and $n a ̀$ in similar, sometimes even identical contexts is consistent with Hopper's (1991: 23) grammaticization principle of layering, which "refers to the prominent fact that very often more than one technique is available in a language to serve similar or even identical functions".

The evolution of adverbials into connectives and hence the close affinity between these two categories is not an unusual phenomenon in languages. Mithun (1988) suggests that

the fluidity of the boundary between discourse adverbials and syntactic conjunctions is significant. The adverbial particles appear to be the source of most clausal coordinating conjunctions. [p. 346]

This can be argued to be the case for Fante nńà, which at present functions as a temporal marker as well as a clausal connective. Lefebvre (2004) suggests that the Fongbe adverbial bó may be the source of the coordinating function of bó ${ }^{24}$

${ }^{23}$ Hopper's definition of persistence was given against the backdrop that grammaticalization was considered as the development of grammatical units from lexical units (see for example Hopper \& Traugott 1993). This definition has been revised and it is now recognized that the phenomenon of grammaticalization includes "how grammatical items develop new grammatical functions" (Hopper \& Traugott 2003). Consequently, the principle of persistence can apply to originally grammatical items which have taken on other grammatical functions like Fante nńà.

${ }^{24}$ Lefebvre (2004: 145) suggests that the connective bó, as in (i), can be traced to the "connective adverb" (bó) which links the content of "the clause it is part of to an event that has been referred to earlier in the discourse", as in (ii).

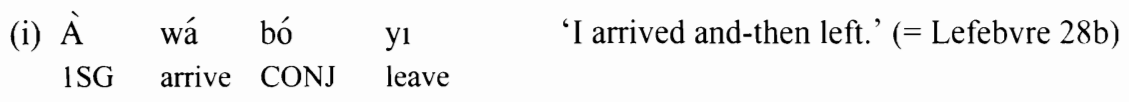

(ii) Bó yi 'Then go.' (= Lefebvre 47b)

Then go 
As mentioned in section 5, the French adverbial puis is assuming a coordinating function, so that it conjoins predicates as well as noun phrases. And indeed, according to Lefebvre, the Haitian clausal connective epi derives from French et puis (and then) - a coordinating connective and an adverbial marker of consecutive events. This kind of relation can be found in English as well, where according to Fretheim (2006), a single form 'then' can function as a truth conditional marker meaning 'at that time' and a non-truth conditional marker of consecutive events, 'and then'.

\section{Conclusion.}

This paper has been concerned with both noun phrase and clausal conjunctions in Akan. With regard to noun phrase conjunction, it has been established that the existing dialectal variation has significant semantic and pragmatic repercussions. Fante encodes a comitative strategy, and the connective which typically expresses a coordinative interpretation in this dialect is underdetermined between a weak (coordinative) and a strong (comitative) interpretation. However, the presence of a separate linguistic form which encodes comitativity makes it natural to think that most occurrences of the mundane noun phrase connective will be assigned a coordinative interpretation without comitiative implications. Asante, on the other hand, has a single noun phrase connective which is underdetermined between a comitative and a coordinative meaning. Contextual information including animacy considerations helps in identifying the intended interpretation. When both conjuncts are inanimate, a comitative interpretation is ruled out. The interpretation of a conjunction with animate conjuncts can go either way. It is significant that there is appreciable variation in the area of noun phrase conjunction among languages, and even within a single language like Akan.

It has been noted that clausal conjunction in Akan is performed by means of the connective nà. Its use indicates that the utterance is to be interpreted as a single unit and it signals that certain inferential relations, including temporal ones, exist between the conjuncts. It was observed that the segmentally identical but high-toned temporal marker ná appears to work equally well when certain temporal relations exist between the conjuncts. In the Twi dialects, it functions as a temporal marker which provides a temporal setting for the proposition expressed in the following conjunct. The Fante equivalent of the temporal marker, nńà, functions like Twi ná meaning 'then' i.e. 'at that time'. In addition, it occurs in utterances where sequential, causal or simultaneous relations exist between the conjuncts. Like the low-toned clausal connective, its use can give rise to an im- 
plied contrastive relation between conjuncts. Even though there is no indication that the temporal marker nnáa will soon usurp the functions of the low-toned coordinating connective, it is significant to note that there appears to be an overlapping communicative function between temporal markers which mean 'at that time' and ordinary clausal connectives. The situation in Fante coupled with that in Fongbe, French and Haitian Creole suggests a close conceptual affinity between the notions 'at that time' and 'after that'. This is evidenced by the fact that in a number of languages the form which means 'at that time' may be used to express other temporal relations in spite of the existence of an ordinary (clausal) connective that may be enriched in context to convey temporal relations between conjuncts (as is the case for Fante nńà and nà, English then and and, French puis and et). Some languages, such as Fongbe and Haitian Creole, have even gone further in this process and originally temporal markers are now functionally coordinating connectives.

\section{REFERENCES}

Abdoulaye, Mahamane L. 2004. "Comitative, coordinating, and inclusory constructions in Hausa." Coordinating Constructions. Typological Studies in Language (TSL) Vol. 58, ed. by Martin Haspelmath. Amsterdam: John Benjamins Publishing Company. Pp. 165-193.

Amfo, Nana Aba Appiah. 2007. “Clausal Conjunction in Akan.” Lingua1 17: 666684.

Anonymous. 1961. Ananse Akuamoa. Bureau of Ghana Languages.

Ansre, Gilbert. 1966. "The verbid: a caveat to 'serial verbs'." Journal of West African Languages 3: 29-32. 
Carston, Robyn. 2002. Thoughts and Utterances: the Pragmatics of Explicit Communication. Oxford: Blackwell Publishing.

Coleman, S. K. 1995. Woana nye Araba nyinsenii. Accra: K. Sam-Woode Limited.

Dakubu, Mary Esther Kropp. 1970. "The categories of the Ga verbal group." Journal of African Linguistics 9: 70-76.

Ellis, Jeffrey \& Lawrence Boadi. 1969. “ 'To be' in Twi." The Verb 'be' and its Synonyms, ed. by John W. M. Verhaar. Foundations of Language Supplementary Series, Vol 9. Dordrecht: Reidel Publishing Company. Pp. 1-71.

Fretheim, Thorstein 2006. "English then and Norwegian da/så compared: a Relevance-theoretic account." Nordic Journal of Linguistics 29: 45-93.

Grice, H. Paul. 1989. Studies in the Way of Words. Cambridge, MA: Harvard University Press.

Heine, Bernd \& Mechthild Reh. 1984. Grammaticalization and Reanalysis in African Languages. Hamburg: Helmut Buske Verlag.

Hopper, Paul J. 1991. "On some principles of grammaticalization." Approaches to Grammaticalization, Vol 1, ed. by Elizabeth Closs Traugott \& Bernd Heine. Amsterdam: John Benjamins Publishing Company. Pp. 17-35.

Hopper, Paul J. \& Elizabeth Traugott. 2003. Grammaticalization. Cambridge: Cambridge University Press. First published 1993.

Lefebvre, Claire. 2004. "Coordination constructions in Fongbe with reference to Haitian Creole." Coordinating Constructions, ed. by Martin Haspelmath. Typological Studies in Language (TSL), Vol 58. Amsterdam: John Benjamins Publishing Company. Pp. 123-164.

Lord, Carol. 1973. "Serial verbs in transition." Studies in African Linguistics 4: 269-295. 
Mithun, Marianne. 1988. "The grammaticization of coordination." Clause Combining in Grammar and Discourse, ed. by John Haiman \& Sandra A. Thompson. Typological Studies in Language (TSL), Vol 18. Amsterdam: John Benjamins Publishing Company. Pp. 331-359.

Schuh, Russell G. 1998. A Grammar of Miya. University of California Publications in Linguistics 130. Berkeley: University of California Press.

Stassen, Leon. 2000. “AND-languages and WITH-languages." Linguistic Typology 4: $1-54$.

Stassen, Leon. 2003. "Noun Phrase conjunction: the coordinative and the comitative strategy." Noun Phrase Structure and the Languages of Europe, ed. by Frans Plank. Berlin: Mouton de Gruyter. Pp. 761-811.

Sperber, Dan \& Deirdre Wilson. 1995. Relevance: Communication and Cognition. $2^{\text {nd }}$ ed. Oxford: Blackwell Publishing.

Trutenau, H. M. J. 1973. "The verbal status of the NP-linker in Ga." Studies in African Linguistics 4: 71-86.

Welmers, William E. 1973. African Language Structures. Berkeley: University of California Press.

Department of Language and Communication Studies Norwegian University of Science and Technology NO-7491, Trondheim, Norway amfo@hf.ntnu.no/nanaamfo@ug.edu.gh [received April 3, 2006 accepted Sept. 16, 2006] 
